\title{
Aplikasi Pengukuran Berat dan Tinggi Badan Anak Balita Menggunakan Metode Radbms Berbasis Python
}

\author{
Juli Sardi ${ }^{1}$, Hamdani $^{2}$, Vito Basjika Pramuja ${ }^{3}$ \\ 1, 2, 3 Universitas Negeri Padang \\ Jl. Prof Dr. Hamka Air Tawar, Padang \\ LuliSardi@ft.unp.ac.id ${ }^{2}$
}

\begin{abstract}
This research is making an application for measuring weight and height of toddlers using the python-based realtime active database management system (RADBMS) method. The goal of this final research is to design and build a weight and height measurement application for children under five that can store its database safely using real-time active database management methods. The design and manufacture of this application for measuring weight and height for toddlers is made with python as a programming language for making the application and MySQL as the database. By using the realtime active database management system method, user applications can use stored databases for reuse display toddler growth charts. And the database that is stored in softcopy in the form of a database can be printed as a hardcopy by becoming a file with the extension .xlsx and then printed afterwards. After testing, the application can be used properly starting from the security of the login interface, the biodata that is stored when inputting data on the data input interface, and when making measurements on the measurement interface.
\end{abstract}

Keywords - Realtime Active Database Management System, Python, MySQL, Database, Softcopy, Hardcopy, Interface, Biodata, Login, Input Data, dan Measurement

\begin{abstract}
Abstrak - Penelitian ini merupakan pembuatan aplikasi pengukuran berat dan tinggi badan anak balita menggunakan metode realtime active database management system (RADBMS) berbasis python. Yang mana tujuan dari penelitian ini adalah merancang dan membuat aplikasi pengukuran berat dan tinggi bada anak balita yang dapat menyimpan database-nya dengan aman menggunakan metode realtime active dattabase management system. Perancangan dan pembuatan aplikasi pengukuran berat dan tinggi balita ini dibuat dengan python sebagai bahasa pemrograman untuk membuat aplikasi-nya dan MySQL sebagai database-nya. Dengan menggunakan metode realtime active database management system, pengguna aplikasi ini dapat menggunakan database yang tersimpan untuk digunakan kembali menampilkan grafik pertumbuhan balita. Dan database yang tersimpan dalam bentuk softcopy dalam bentuk database bisa dicetak menjadi hardcopy dengan mengkonversi menjadi file berekstensi .xIsx dan diprint setelahnya. Setelah dilakukan pengujian aplikasi yang dapat digunakan dengan baik mulai dari keamanan login interfacenya, biodata yang disimpan saat melakukan input data pada input data interface, dan saat melakukan pengukuran pada measurement interface.
\end{abstract}

Kata kunci - Realtime Active Database Management System, Python, MySQL, Basis data, Softcopy, Hardcopy, Antarmuka, Biodata, Login, Input Data, dan Pengukuran.

\section{PENDAHULUAN}

Dewasa ini teknologi yang dipakai pada instansi di daerah pinggiran kota hingga ke desa masih terbilang konvensional. Seperti pengukuran tinggi dan berat balita di Posyandu. Pengukuran tinggi yang dilakukan menggunakan penggaris atau sejenis. Sedangkan untuk pengukuran berat dilakukan dengan timbangan. Berdasarkan kedua pengukuran tadi, sering terjadi human error sehingga hasil sebenarnya tidak sesuai karena faktor seperti salah pembacaan oleh mata pengukur. Selain itu, untuk rekam data yang digunakan adalah berupa tulisan tangan ke buku rekam medis. Hal ini membuat hasil rekam data tersebut tidak tersimpan dengan baik dan belum berbentuk database sehingga tidak bisa dimanfaatkan untuk proyeksi trend grafik kesehatan Anak Balita pada skala yang lebih besar.
Agar lebih efisien, pengukuran tinggi dan berat balita dilakukan dengan alat ukur yang mempunyai presisi yang lebih tinggi. Nantinya alat pengukuran alat ini akan dihasilkan dengan output yang jelas, yaitu komputer. Karena pengaplikasian alat ini berbasis komputer. Selain itu, database dari hasil pengukuran tadi disimpan di komputer. Sebelumnya, penelitian ini pernah dilakukan dan berhasil dengan baik. Dalam pembuatannya, alat sebelumnya hanya menggunakan PC desktop sebagai output hasil ukur dan sumber tegangan bagi alat tersebut untuk hidup [1].

Pada penelitan ini, akan dirancang aplikasi database untuk sistem pengukuran dan berat dan tinggi balita pada pada Posyandu. Penulis akan menggunakan metode atau teknik Realtime Active Database Management System (RADBS) [2-4]. Active Database Management System (ADBMS) sendiri adalah suatu sistem database yang tidak 
sekedar menyimpan data tetapi bisa juga melakukan aksi tertentu karena ada suatu event dengan memasukkan elemen dinamis serta mempunyai kemampuan memantau event untuk mendeteksi ketika data tertentu dimasukkan, dihapus, diubah, atau dipilih kemudian secara otomatis mengeksekusi suatu aksi sebagai respon dari event yang terjadi dan kondisi tertentu terpenuhi. Sedangkan Realtime yang maksudnya adalah ADBMS tadi bisa dilakukan aksi atau manipulasi tepat pada saat itu juga dan terus berjalan tanpa dipengaruhi waktu.

Nantinya, setelah database hasil pengukuran tinggi dan berat badan balita disimpan, hasil pengukuran dari pengukuran pertama dan kedua dapat dibandingkan hingga ke bentuk grafik. Biasanya, database mendapatkan input dari operator manusia, maksudnya adalah dari input komputer yang diberikan oleh manusia selaku operator. Seperti penelitian sebelumnya mengenai ADBMS dengan monitoring operator [5-8]. Maka dari, penelitian yang pernah dilakukan sebelumnya, penelitian ini dikerjakan dengan input pembacaan dari sensor Ultrasonik dan sensor Load Cell yang akan dibaca dan diinformasikan kepada Arduino, yang nantinya akan masuk langsung ke database.

Program yang digunakan untuk merancang aplikasinya adalah bahasa pemrograman Python. Bahasa pemrograman Python digunakan karena bahasa pemrograman ini sangat baik dan dianjurkan untuk tujuan analisis data. Bahasa pemrograman Python juga lengkap library-nya, sehingga bisa digunakan baik untuk membuat Graphical User Interface (GUI), menghubungkan ke Arduino, hingga akses ke database. Jadi, dalam penelitian ini hanya akan memfokuskan meggunakan bahasa pemrograman Python untuk semua pengerjaan. Pada penelitian kali ini, akan difokuskan pekerjaan pembuatan hanya pada aplikasinya [9-10]. Karena, hardware yang digunakan adalah hardware yang sudah ada pada penelitan sebelumnya. Jadi, pada penelitian ini akan dikembangakan pengaplikasian menjadi lebih efisien hasilnya.

\section{METODE}

Pada penelitian ini, metode yang digunakan adalah perancangan dan pembuatan aplikasi. Aplikasi ini dirancang untuk digunakan dengan alat pengukur dan berat dan tinggi balita yang telah dijelaskan.

\section{A. Blok Diagram}

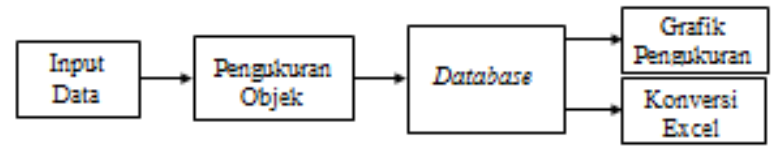

Gambar 1. Blok Diagram

Blok-Blok diagram perancangan dapat dijelaskan sebagai berikut:

1. Input Data

Input Data berfungsi sebagai syarat pertama untuk melakukan pengukuran. Pengukuran tidak dapat dilakukan sebelum input data dilakukan. Nantinya, data yang telah di-inputkan akan menjadi kata kunci untuk mencari database yang diperlukan.

2. Pengukuran Objek

Pengukuran Objek dimana objeknya adalah balita yang akan diukur. Hasil ukur dari pengukuran objek inilah yang akan menjadi database berdasarkan dari data yang di-input-kan.

3. Database

Database ini berupa biodata yang di-inputkan dan hasil pengukuran dari balita yang diukur. Nantinya, database ini dapat difungsikan menjadi grafik pengukuran dan pertumbuhan balita. Selain itu, database ini juga dapat dikonversikan menjadi file excel untuk dicetak.

4. Grafik Pengukuran

Grafik Pengukuran ini merupakan hasil ukur tinggi dan berat yang dilakukan kepada balita diambil dari database. Database ini bersifat aktif yang artinya bisa terus dimanfaatkaan dan digunakan dimana salah satunya adalah menunjukkan pertumbuhan balita dalam bentuk grafik.

5. Konversi Excel

Konversi Excel ini berfungsi untuk memanfaatkan database biodata beserta hasil ukur dicetak nantinya. Database yang ada pada laptop dikonversikan menjadi bentuk file berupa fomat .xlsx atau biasa sering disebut excel. Lalu setelahnya bisa dicetak bila diperlukan hardcopy-nya.

\section{B. Prinsip Kerja Alat}

Aplikasi ini dibuat untuk memenuhi kebetuhan pencatatan data hasil pengukuran berat dan tinggi badan balita yang ada di Posyandu. Dengan dibantu hardware yang telah dibuat sebelumnya, aplikasi ini dibuat secara user-friendly untuk mempermudah orang-orang di Posyandu untuk melakukan pekerjaannya tanpa sulit menggunakannya.

Adapun prinsip kerja alat ini didasarkan pada pengukuran yang dilakukan sensor Load Cell untuk mengukur berat badan balita dan sensor Ultrasonic untuk mengukur tinggi badan balita. Setelah diukur, hasil pengukuran sementara akan dikirim ke Mikrokontroler Arduino yang nantinya akan disimpan secara permanen pada database di penyimpanan memori yang ada pada PC (Personal Computer). Setelah data tersimpan, pengguna bisa melakukan aksi lain sesuai pilihannya seperti; mengukur lagi pengukuran yang dilakukan, dan menyelesaikan pengukuran pertama. Pengguna aplikasi ini dapat membuat dan mengubah biodata objek pada aplikasi ini. Pengguna aplikasi ini juga dapat membandingkan data langsung setelah terukur sesuai dengan keinginan yang ingin dilakukan. Aksi database yang aktif dan bisa terusmenerus digunakan inilah yang disebut Realtime Active Database Management System. Nantinya database dapat dimanfaatkan untuk melihat pertumbuhan balita berdasarkan hasil ukur setiap periode waktu yang telah 
ditentukan dan bisa pula mengkonversikan database menjadi file berupa formar .xlsx yang nantinya bisa dicetak menjadi hardcopy bila diperlukan.

\section{Flowchart Sistem}

Secara sederhananya, flowchart cara kerja sistem Aplikasi Perngukuran Berat dan Tinggi atau bisa disebut APBT dapat dilihat pada gambar 2 .

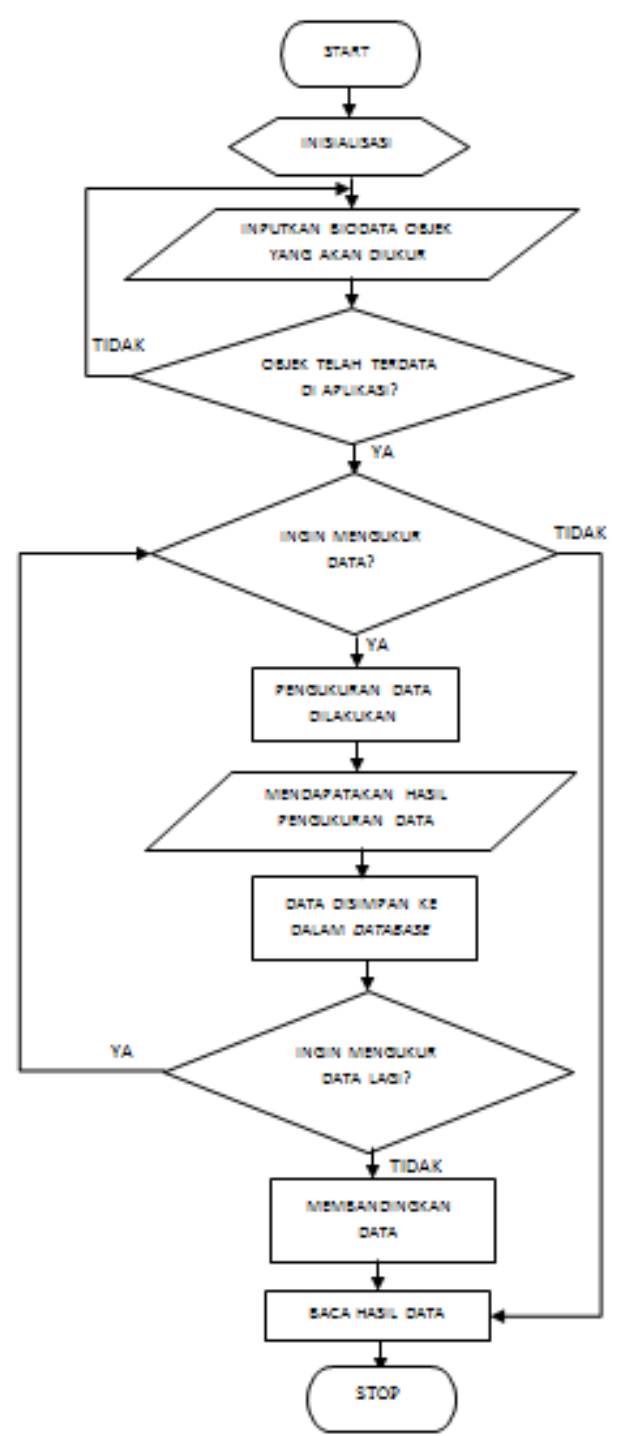

Gambar 2. Flowchart Sistem

Aplikasi pengukuran yang akan dibuat didasarkan pada aplikasi yang telah ada sebelumnya, dengan tambahan pengembangan untuk membandingkan data. Aplikasi ini memberikan pilihan bagi pengguna nya untuk melakukan pengukuran data baru, hanya membaca data yang telah tersimpan di database atau membandingkan hasil pengukuran data yang telah dilakukan beberapa kali.

\section{Alat Dan Bahan}

Adapun alat dan bahan yang digunakan dalam pembuatan aplikasi pengukuran berat dan tinggi badan balita adalah sebagai berikut:

1. Hardware

Hardware yang digunakan dalam pembuatan aplikasi ini adalah penelitian yang telah dibuat pada penelitian sebelumnya [2]. Karena, dalam penelitian ini hanya difokuskan pada pembuatan aplikasinya saja, tidak ikut serta membuat hardware nya.

2. Software

Software yang digunakan hanyalah bahasa pemrograman Python untuk pembuatan aplikasinya. Dimana bahasa pemrograman Python digunakan untuk membuat Graphical User Interface (GUI), akses ke database, akses ke sistem penginformasian dari Arduino, hingga penampilan output perbandingan data berupa grafik.

\section{E. Perancangan Umum Sistem}

Agar aplikasi ini dapat digunakan dengan baik saat digunakan, aplikasi ini harus dirancang dengan terstruktur. Tentunya dengan perancangan yang baik kesalahan saat penggunaan seperti error tidak akan timbul. Adapun perancangan umum sistem dari aplikasi ini adalah sebagai berikut:

\section{Login Interface}

Login Interface berfungsi sebagai keamanan aplikasi sebelum menggunakan aplikasi ini. Ini dibuat agar tidak semua dan sembarang orang bisa menggunakan aplikasi, karena dalam aplikasi ini berisi database penting yang perlu dijaga. Ini juga merupakan salah satu keunggulan aplikasi ini.

2. Input Data Interface

Input Data Interface berfungsi untuk pengisian data / biodata dari balita yang akan diukur. Dalam interface ini akan dibuat menu berupa kolom-kolom untuk pengisian data / biodata yang akan diukur. Akan disediakan pula tombol-tombol yang berfungsi untuk membuat data baru, menghapus data, dan memperbarui data yang akan diubah. Pada interface akan ditampilkan tabel yang berisi balita yang sudah tersimpan data / biodatanya.

3. Measurement Interface

Measurement Interface atau antarmuka pengukuran adalah interface yang berfungsi untuk mengukur balita dan penyimpannya. Akan disediakan tomboltombol yang berfungsi untuk menyimpan, menghapus dan mengedit hasil ukurnya. Ada pula tombol yang berfungsi untuk melihat grafik pertumbuhan balita berdasarkan hasil ukur yang telah didapat. Juga ada tombol untuk mengkonversikan database menjadi file dengan format .xIsx, ini diperlukan jika ingin mencetak database menjadi hardcopy jika diperlukan nantinya. 


\section{HASIL DAN PEMBAHASAN}

Pada bagian ini, akan dilakukan pengujian untuk mendapatkan hasilnya dan untuk dibahas, apakah aplikasinya berjalan dan berfungsi dengan baik dan semestinya atau tidak. Pengujian dilakukan menyangkut beberapa hal sebagai berikut:

\section{A. Pengujian APBT (Aplikasi Pengukur Berat dan Tinggi)}

Dalam melakukan pengukuran balita digunakan dua jenis pengujian menggunakan alat yang berbeda, yaitu dengan alat ukur APBT dan alat ukur konvensional. Saat melakukan pengujian, alat ukur APBT digunakan pada pengukuran pertama karena nantinya akan disimpan biodata balita berupa database ke laptop. Pengukuran kedua dilakukan agar membandingkan hasil ukur menggunakan alat ukur APBT dan hasil ukur menggunakan alat ukur konvesional yang nilainya adalah nilai pasti atau nilai fakta.

Adapun dalam pengujian alat ukur APBT ini penulis langsung melakukan pengukuran kepada beberapa balita agar dapat memastikan alat ukur ini berfungsi dengan baik atau tidak. Pengujian langsung kepada balita ini juga berfungsi untuk mengimplementasikan langsung tujuan dan manfaat alat ukur APBT ini dibuat.

Cara kerja pengukuran menggunakan alat ukur pada APBT adalah dengan meletakkan objek yang akan diukur diantara pembatas yang telah disediakan. Dimana sensor jarak ultrasonik akan mengukur panjang objek berdasarkan jarak antar pembatas. Karena objek yang akan diukura nantinya adalah balita, maka untuk mengukur balita tersebut balita perlu berbaring diatas alat APBT agar pengukuran tinggi badan akan dilakukan secara horizontal. Maka, nilai panjang yang terukur adalah nilai tinggi balita tersebut. Sedangkan untuk beratnya akan terukur secara otomatis karena load cell yang tertanam di dalam alat ukur APBT akan mengukur berat objek yang diletakkan di atasnya.

Dalam pengujian alat ukur APBT ini terdapat langkah-langkah cara penggunaannya. Adapun cara langkah-langkah cara menggunakan alat ukur APBT ini adalah sebagai berikut.

1. Pastikan alat ukur APBT seimbang dengan permukaan datar dan tidak terbebani objek apapun sebelum diukur.

2. Hubungkan serial port yang ada pada APBT ke laptop / PC.

3. Buka aplikasi database pada laptop. Penulis menggunakan aplikasi XAMPP. Klik tombol Start pada baris Apache dan Start pada baris MySQL seperti tampak pada gambar 3 .

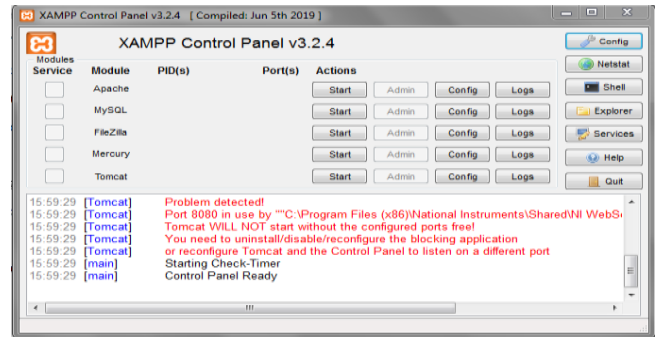

Gambar 3. Control panel XAMPP sebelum terhehubung ke database

Jika sudah, background pada tulisan Apache dan $M y S Q L$ akan berwarna hijau yang mengindikasikan bahwa aplikasi sudah terhubung ke database secara langsung, seperti yang dapat dilihat pada gambar 4 .

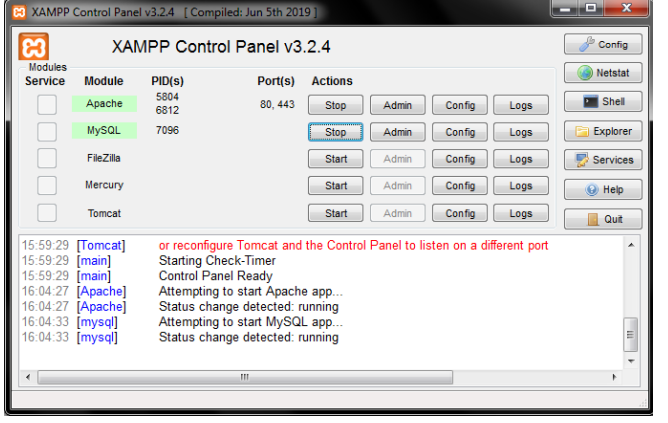

Gambar 4. Control panel XAMPP setelah terhubung ke database

4. Setelah terhubung ke database, jalankan aplikasi alat ukur database. Jika sudah dijalankan akan tampak login GUI (Graphical User Interface) seperti tampak pada gambar 5 .

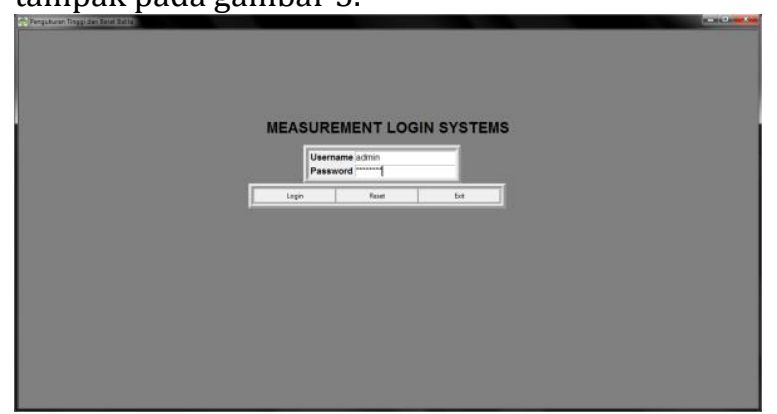

Gambar 5. Login Interface

5. Masukkan username dan password lalu login ke aplikasi tersebut.

6. Seteleh login, akan ada tampilan home aplikasi. Di interface ini pengguna dapat pencarian database balita berdasarkan informasi terkait yang dimasukkan. Jika ingin membuat data baru untuk melalukan pengukuran balita yang baru pula, masukkan informasi secara lengkap pada biodata yang tertera secara lengkap. Jika sudah, klik New. Adapun pilihan Update berguna memperbarui informasi yang salah atau informasi terbaru dari salah satu balita, Clear untuk membersihkan semua kolom biodata yang tertera, dan Delete untuk 
menghapus salah satu data yang ingin dihapus. Tampilan Input data interface dapat dilihat pada gambar 6.

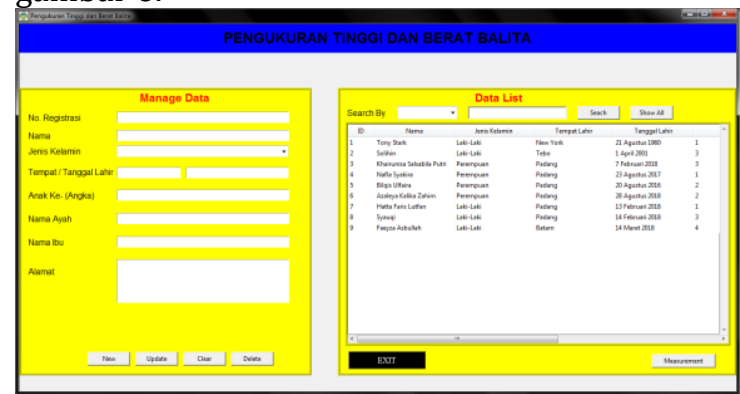

Gambar 6. Input data Interface

7. Jika sudah memilih balita mana yang ingin diukur, klik Measurement. Tampilan GUI akan berubah seperti yang terlihat pada gambar 7 .

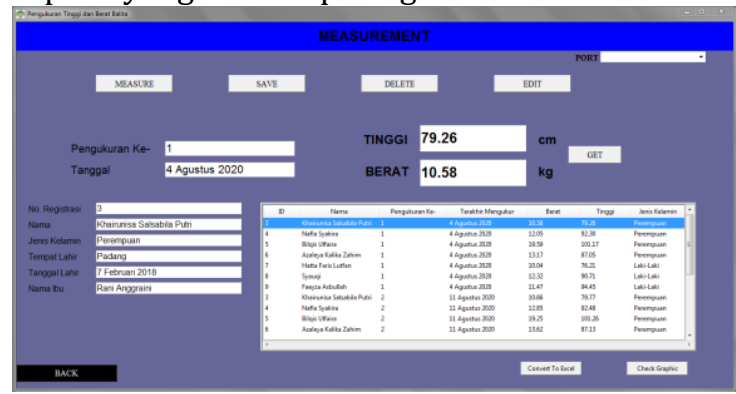

Gambar 7. Measurement Interface

8. Untuk mengukur, isi terlebih dahulu kolom pengukuran ke-berapakah yang sedang dilakukan dan tanggal pengukuran.

9. Jika sudah, klik Measure dimana aplikasi tersebut akan mulai menghitung pengukuran realtime dari hardware alat ukur APBT yang akan ditampilkan pada kolom Tinggi dengan satuan $\mathrm{cm}$ dan Berat dengan satuan kg. Karena sifat sensor ultrasonik pada alat bersifat endless atau terus mengukur tanpa henti, tombol Get perlu di-klik agar pengukuran berhenti. Meskipun menggunakan tombol Get, hasil ukurnya terbilang cukup akurat.

10. Apabila pengukuran telah dilakukan dan didapat hasil ukurnya, klik tombol Save agar hasil ukur berdasarkan biodata terkait disimpan ke database.

11. Pilih hasil ukur yang tertera pada tabel jika ingin melihat lagi hasil ukur yang telah dilakukan sebelumnya. Klik Delete jika ingin menghapus hasil ukur yang salah atau tidak diinginkan dan klik Edit jika ingin memperbaiki data tertentu dari hasil ukur tersebut.

12. Klik Check Graphic jika ingin melihat hasil ukur balita dalam bentuk grafik dan melihat pertumbuhan balita tersebut apakah pertumbuhannya normal atau tidak. Adapun bentuk grafik yang akan ditampilkan adalah seperti pada gambar 8 berikut.

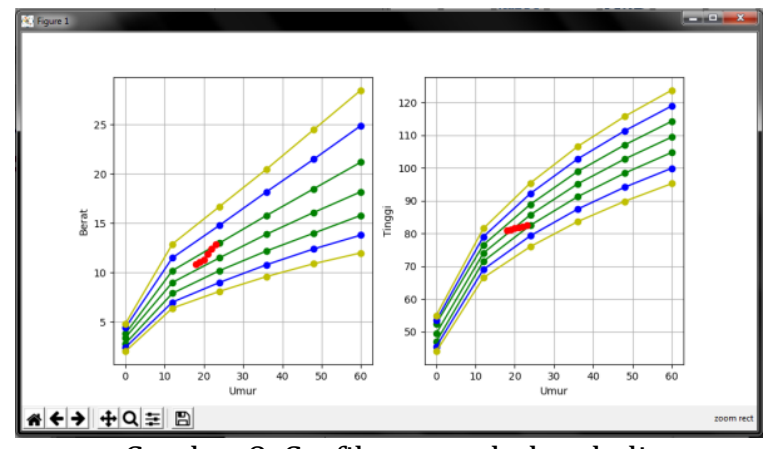

Gambar 8. Grafik pertumbuhan balita

Adapun tampilan grafik jika sudah di-zoom pada kendali navigasi nya akan tampak seperti gambar 9.

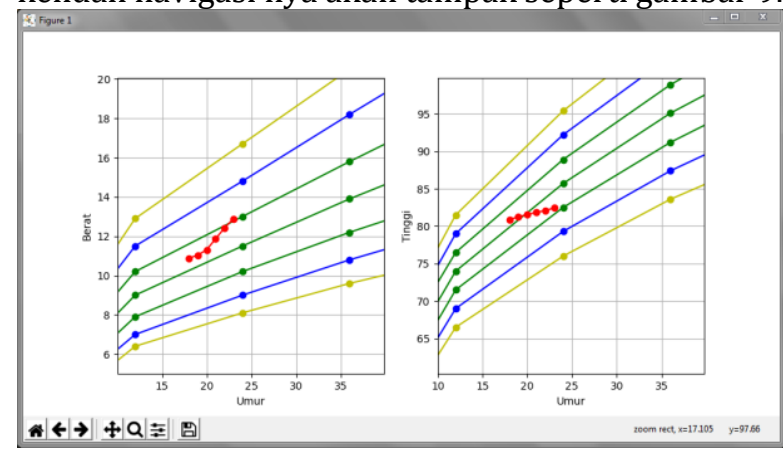

Gambar 9. Grafik pertumbuhan balita jika di-zoom

13. Klik Convert To Excel untuk mengubah format database menjadi excel. Ini dilakukan jika pengguna aplikasi ingin menggunakan data tadi untuk rekapitulasi data apabila ingin dicetak nantinya. Adapun bentuk file excel yang akan dihasilkan adalah pada gambar 10 berikut.

\begin{tabular}{|c|c|c|c|c|c|}
\hline 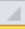 & A & B & c & D & E \\
\hline 1 & nama & pengukuran & tanggal & berat & tinggi \\
\hline 2 & Khairunisa Salsabila Putri & 1 & 4 Agustus 2020 & 10.58 & 79.26 \\
\hline 3 & Khairunisa Salsabila Putri & 2 & 11 Agustus 2020 & 10.66 & 79.77 \\
\hline 4 & Khairunisa Salsabila Putri & 3 & 18 Agustus 2020 & 10.52 & 79.82 \\
\hline
\end{tabular}

Gambar 10. Data perkembangan balita yang dikonversikan menjadi file excel

\section{B. Pembahasan Program pada APBT}

Adapun bagian-bagian program yang akan digunakan untuk dibahas adalah sebagai berikut.

1. Inisialisasi macam-macam modules yang akan digunakan.

Libraries atau modules yang akan diinisialisasi adalah libraries yang hanya dibutuhkan untuk aplikasi tersebut, diantaranya adalah:

a. Line 1 sampai line 4 merupakan tampilan GUI, pemberitahuan form biodata hingga pesan pemberitahuan seperti error.

b. Line 5 merupakan modul untuk akses ke database, komunikasi serial, dan akses untuk mengkonversikan file menjadi .xlsx (file excel)

c. Line 6 juga merupakan akses komunikasi serial 
d. Line 7 adalah modul untuk menghasilkan tampilan grafik data nantinya

e. Line 8 merupakan modul untuk pengolahan data yang tak beraturan menjadi beraturan dan bisa diolah (dataframe)

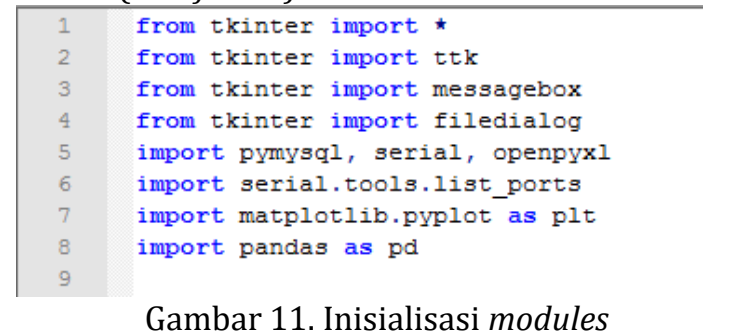

2. Inisialisasi function atau method

Function atau Method adalah program yang dibuat untuk menjalankan suatu tugas tertentu. Dengan menggunakan function, program bisa digunakan berkali-kali hanya dengan mendefiniskan fungsi sesuai kebutuhan program itu sendiri. Sehingga akan lebih efisien untuk pembuatan aplikasinya. Adapun macam-macam fungsi yang dibuat adalah sebagai berikut:

a. Fungsi untuk membuat tampilan GUI berubahubah.

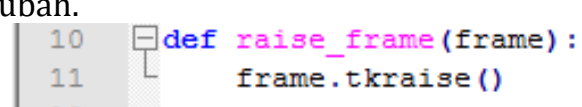

Gambar 12. Fungsi untuk membuat tampilan GUI berubah-ubah

b. Fungsi keamana login agar aplikasi tidak mudah digunakan sembarangan orang. Adapun username dan password nya bisa diubah terlebih dahulu sebelum aplikasi benar-benar akan digunakan.

def login_system():

$u=(\overline{\text { Username }} \cdot \operatorname{get}())$

$\mathrm{p}=($ Password.get ()$)$

if $(u=($ 'admin') and $p=($ 'password') $)$

raise frame (Window2)

else:

messagebox.showinfo('Login Systems', 'Akses Ditolak!!\nCoba Lagi!!') Reset ()

Gambar 13. Fungsi keamanan login pada aplikasi

c. Fungsi tombol reset pada login page.

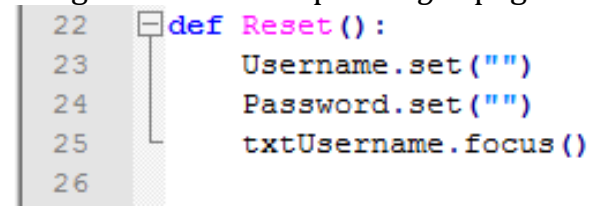

Gambar 14. Fungsi tombol reset pada login page d. Fungsi tombol exit pada login page

ef iExit ()

iExit = tkinter,messagebox.showinfo("Login Systems", "You decided to Exit!!") root.destroy ()

Gambar 15. Fungsi tombol exit pada login page

e. Fungsi akses komunikasi serial yang terhubung pada desktop

تdef serial_ports(): return serial.tools.list_ports.comports()

Gambar 16. Fungsi akses komunikasi serial

f. Fungsi akses pilihan komunikasi serial yang terserdia

$\exists$ def on select (event $=$ None) : print('event widgets : ', event.widget.get()) print ('combobox : ', portCombo.get ())

Gambar 17. Fungsi akses pilihan komunikasi serial yang tersedia

g. Fungsi penyesuaian data pada database setelah dilakukan suatu perubahan. Perubahan yang dimaksud seperti penambahan, pengurangan, perubahan, dan lain-lain.

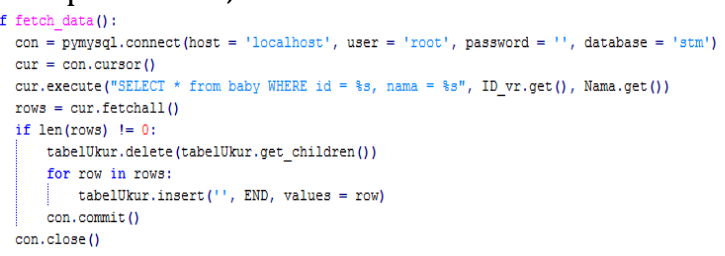

Gambar 18. Fungsi penyesuaian data pada database

h. Fungsi penghentian pengukuran data terusmenerus

50 Đdef pause () :

52 root.after_cancel (update)

Gambar 19. Fungsi penghentian pengukuran data terusmenerus.

i. Fungsi pembacaan nilai data dari Arduino ke desktop

def nilaisensor(): if True:

global nilaiUkurTinggi, nilaiUkurBerat, root, update

$\mathrm{x}=$ arduinoSerialData $\cdot$ readline ()

values $=\operatorname{str}(\mathrm{x} \cdot \operatorname{decode}() \cdot \operatorname{strip}())$

$\mathrm{y}=$ values.split ('\#')

Tinggi.set $(\mathrm{y}[0])$

Berat.set (y [1])

update $=$ root. after $(700$, nilaisensor $)$

Gambar 20. Fungsi pembacaan nilai data 
j. Fungsi tombol add pada input data interface

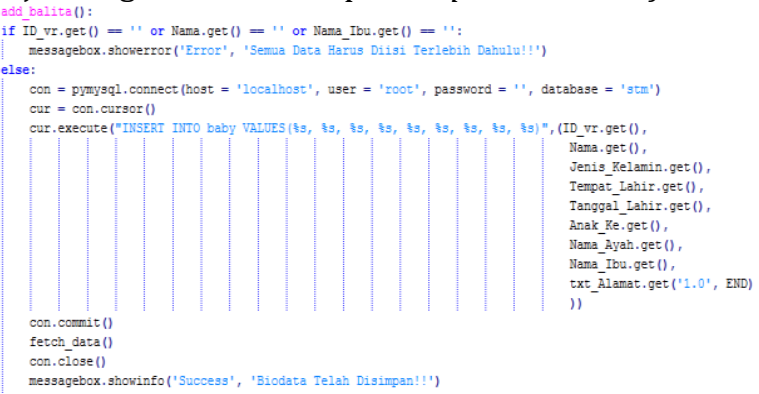

Gambar 21. Fungsi tombol add pada input data interface

k. Fungsi tombol clear pada input data interfaces

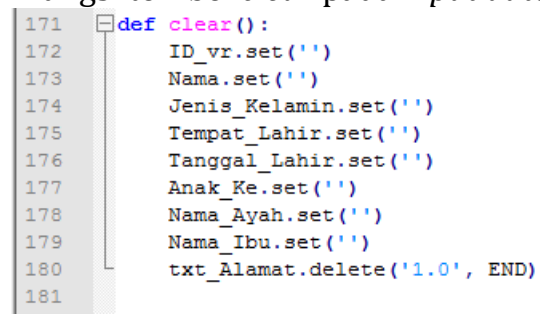

Gambar 22. Fungsi tombol clear pada input data interface

1. Fungsi menampilkan biodata pada form

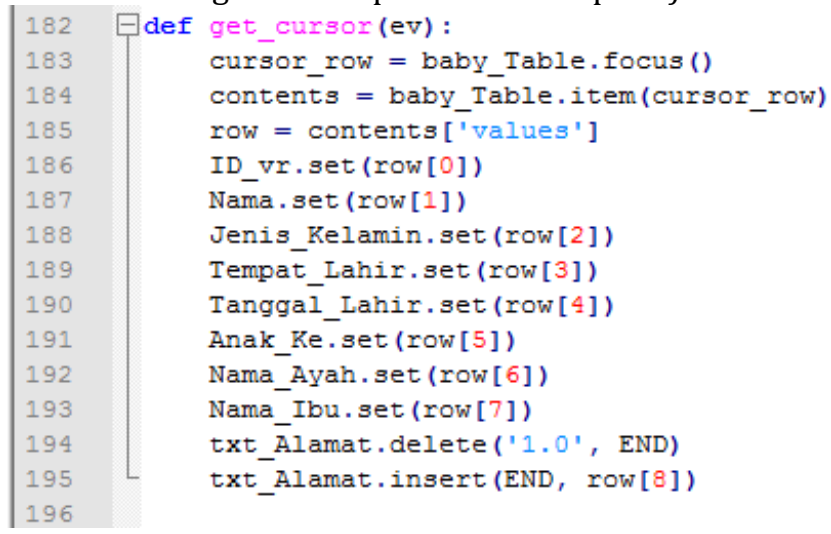

Gambar 23. Fungsi menampikan biodata pada form

m.Fungsi memperbarui biodata

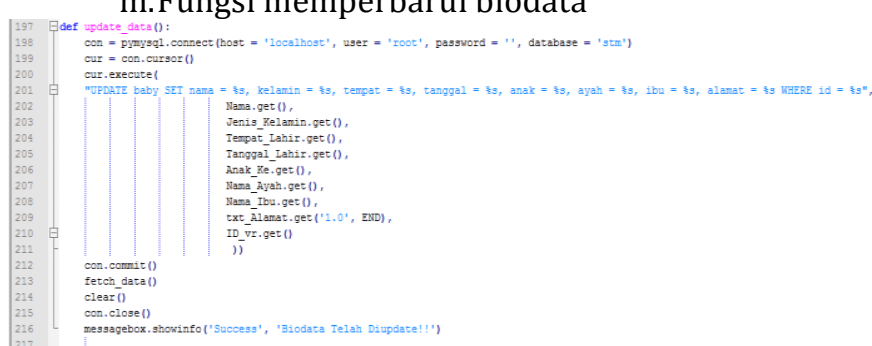

Gambar 24. Fungsi memperbarui biodata yang ada pada database n. Fungsi menghapus biodata

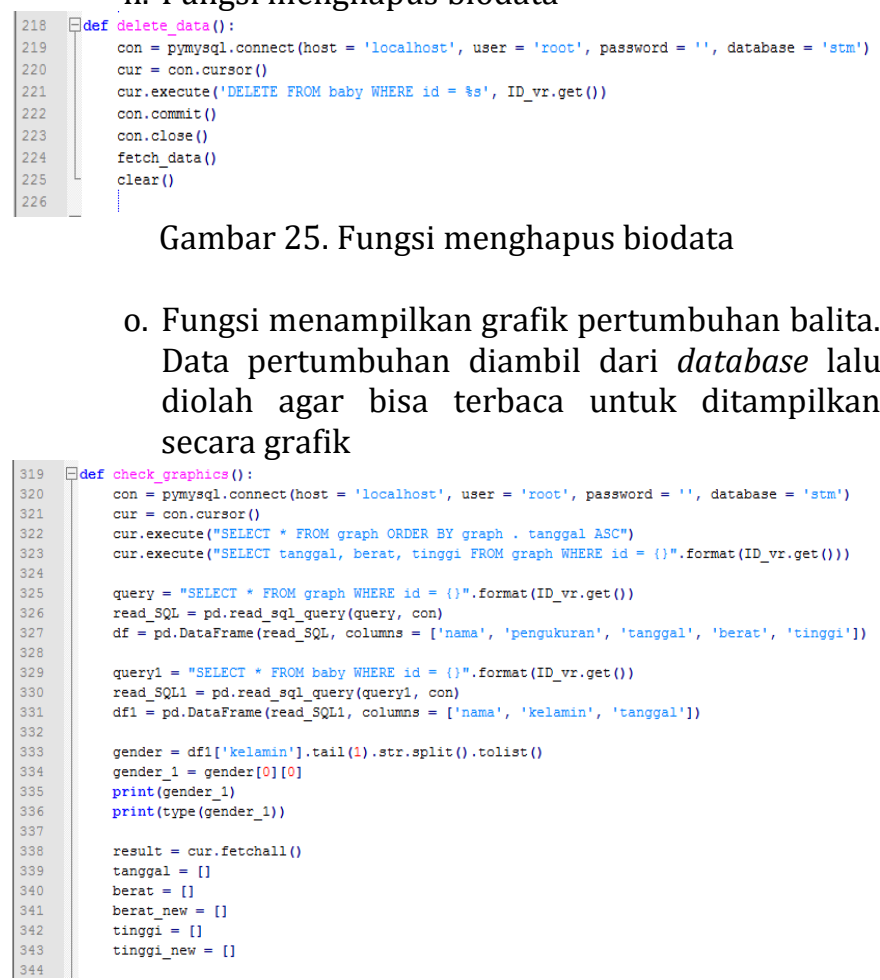

Gambar 26. Fungsi menampilkan grafik pertumbuhan balita

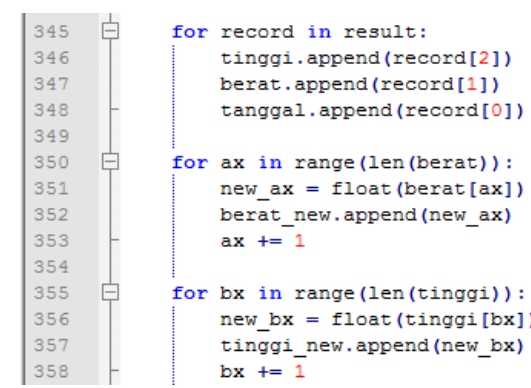

Gambar 27. Fungsi menampilkan grafik pertumbuhan balita (lanjutan pertama)

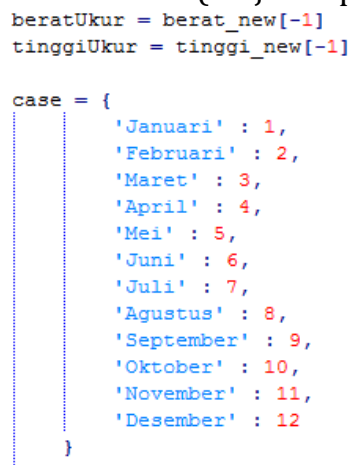

bulanLahir $=$ df1 ['tanggal'].tail (1).str.split (). tolist () bulanLahir 1 = bulanLahir [0] [1]

bulanLahir 2 = case.get (bulanLahir 1 )

tahunLahir_1 = int (bulanLahir [0] [2])

bulanUkur $=$ df ['tanggal'].str.split ().tolist (

Gambar 28. Fungsi menampilkan grafik pertumbuhan balita (lanjutan kedua) 


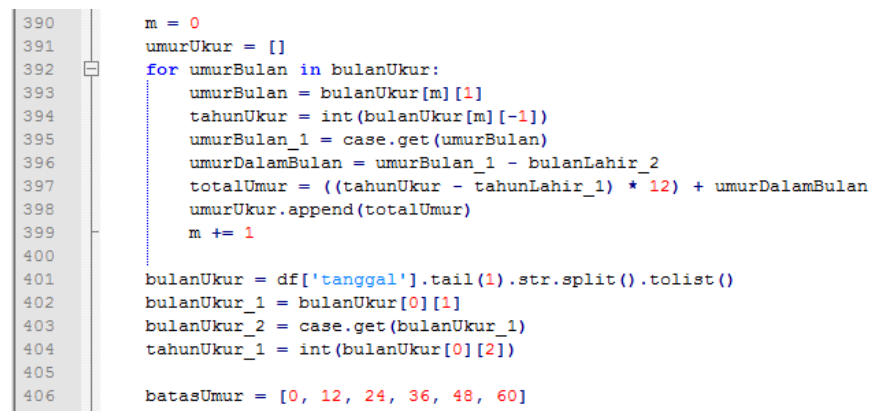

Gambar 29. Fungsi menampilkan grafik pertumbuhan balita (lanjutan ketiga)
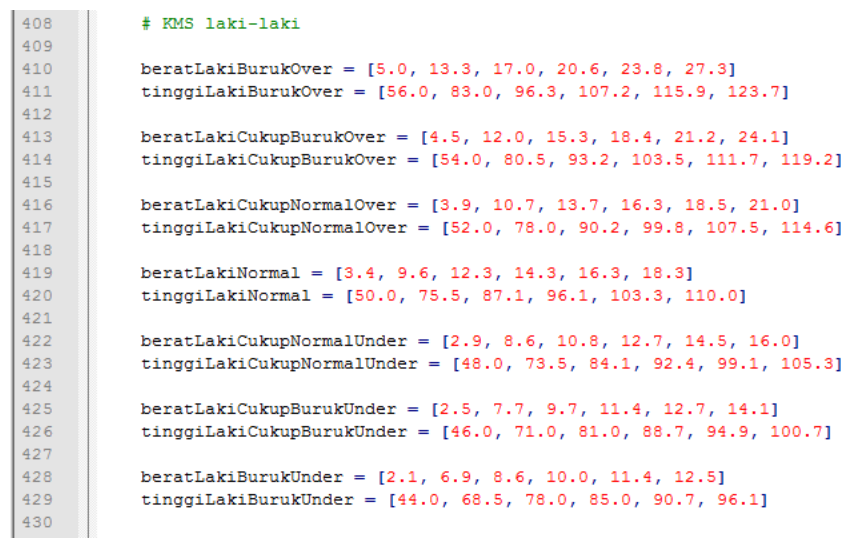

Gambar 30. Fungsi menampilkan grafik pertumbuhan balita (lanjutan keempat)

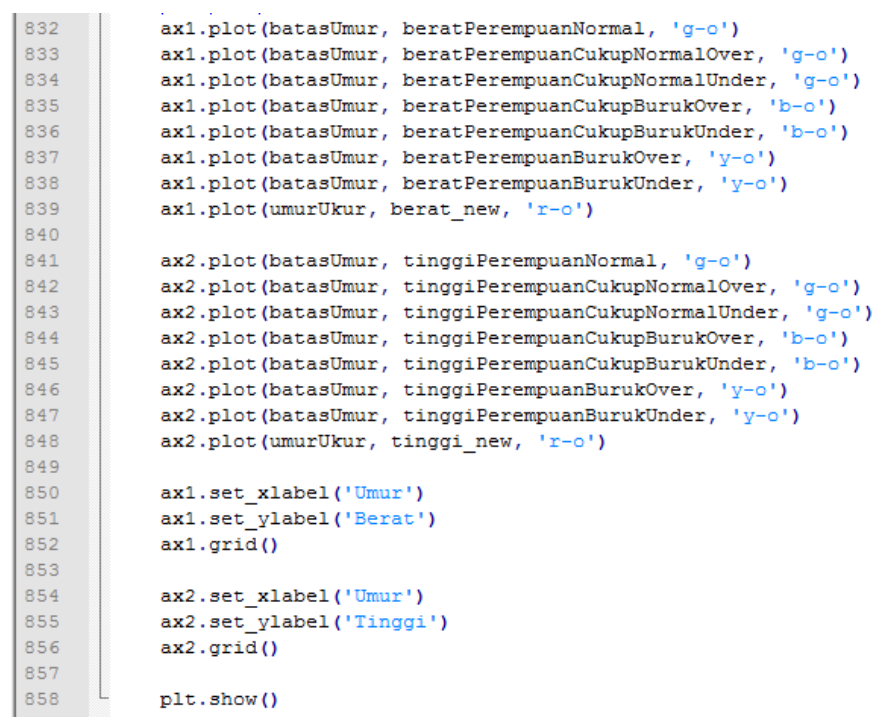

Gambar 32. Fungsi menampilkan grafik pertumbuhan balita (lanjutan keenam)

p. Fungsi mengkonversi database menjadi file excel (.xlsx)

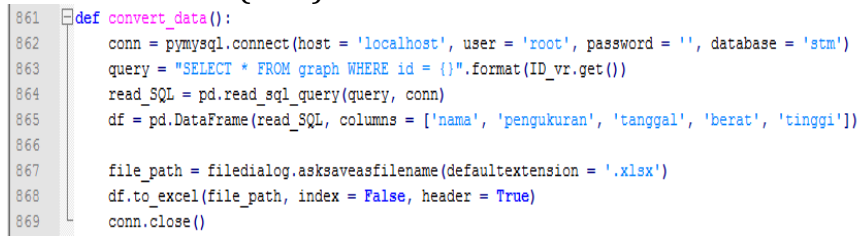

Gambar 33. Fungsi mengkonversikan database menjadi file excel

\section{PENUTUP}

Aplikasi yang diuji telah bekerja dengan baik sesuai dengan rancangan yang telah dilakukan sebelumnya. Data yang tersimpan akurat, sesuai dengan alat (hardware) yang mengukur hasil pengukurannya. Database dapat disimpan dengan baik dan aman, serta bisa digunakan kembali sesuai dengan metode yang disebutkan sebelumnya, yakni Realtime Active Database Mangagement System.

\section{REFERENSI}

[1] R. Patrio Timi, "Rancang Bangun Pengukur Berat Dan Tinggi Badan Balita Otomatis Berbasis Mikrokontroler", Rancang Bangun Pengukur Berat Dan Tinggi Badan Balita Otomatis Berbasis Mikrokontroler, 2019.

[2] S. Anita, and K. S. Devendra, "Real Time Application of Database Management System Using Monitoring of Input", International Journal of Advanced Engineering Research and Science (IJAERS), 1(3), 8-11.

[3] Juli Sardi, Habibullah, Risfendra, “ Rancang Bangun Sistem Monitoring Pertumbuhan dan Berat Badan Balita Berbasis Data pada Posyandu", Jurnal Elkha, Vol.11 No.2, 2019. 
[4] Bella Hardiyana dan Irfan Suendi, "Sistem InformasiPendataan Bayi," Jurnal Teknologi dan Informasi, Vol 1, no 3, 2013.

[5] Nabila Sholiha dan Sri Kusamadewi, "Sistem Informasi Posyandu Kesehatan Ibu dan Anak," Prosiding Seminar Nasional dan Informatika Ke 2, 2015.

[6] Indrajani, "Membangun Basis Data Posyandu Menuju Indonesia Sehat Sentosa," Jurnal Comtech, Vol. 4, no.2, pp.618-626, 2013.

[7] Nofriadi dan Alpin Aperta, "Perancangan Aplikasi Timbangan Bayi pada Posyandu denga Standar Antropometri WHO 2005 Menggunakan Arduino Uno R3, Ms.Visual Studio.Net 2010 dan My SQL," Jurnal CoreIT, Vol.3, No.1, pp. 1-8, Juni.2017

[8] Wen Hao, Dong Xiao-rui, Ma Yu-cheng and Nan Jinrui, "The Research of the Databases Connection Methods in Lab View Based on ADO", International Conference on Computer Application and System Modeling (ICCASM), 2010.

[9] Xuejie Wei, Jie Zhang, Zhao Yang and Zhen Zhao, "The Management System for Data Acquisition based on LabView and LabSQL,", Third International Conference on Information Science and Technology, March 23-25, 2013.

[10] Song qiang, Shi Yanfang and Lv Chenguang, “ Database Design in Data Acquisition System for Electric Vehicle's Driving Motor Test Bench," Fifth Conference on Measuring Technology and Mechatronics Automation, 2013.

\section{Biodata Penulis}

Juli Sardi, lahir di Pulau Punjung, 18 Juli 1987. Sarjana Pendidikan di Jurusan Teknik Elektro FT UNP 2010. Tahun 20013 memperoleh gelar Master Teknik di jurusan Teknik Elektro Pasca sarjana ITS. Staf pengajar di jurusan Teknik Elektro FT UNP sejak tahun 2014- sekarang. 